The material is of particular significance in a theoretical context. According to Schumpeter's theory, economic development is due to the activities of the creative entrepreneur who blazes the trail (in our case Jacques Laffitte). As soon as he has done so, he finds first a few followers (in our case Baguenault, Greffulhe, Hottinguer, and the Delesserts) until there is a rush into the new field (in our case the Périer group). Such a rush is bound to lead to overexpansion and crisis. This aspect both of economic development and of the business cycle can be verified by the early history of French investment banking as in a test tube.

Fritz RedLich

Belmont, Mass.

\title{
A New Book for Members of the Business Historical Society
}

The members of the Society will receive some time next month Pepperell's Progress: History of a Cotton Textile Company, 1844-1945, by Evelyn H. Knowlton. This volume will be number 13 in the Harvard Studies in Business History.

\section{Announcing a Change in the $F_{\text {requency }}$ of Publication of the Bulletin}

At the latest meeting of the Council of the Business Historical Society, Inc., it was decided to change the Bulletin to a quarterly. It was not the intention thereby to increase the total annual size of the Bulletin but rather to make it possible to introduce greater variety and flexibility in the content of the individual issues. In the present issue the remaining numbers for the calendar year of 1948 are incorporated in one. The first number of the quarterly will appear in March of next year and every third month thereafter. 